\title{
Heterogeneous analysis of pollution abatement via renewable and non-renewable energy: lessons from investment in G20 nations
}

\author{
Kazeem Bello Ajide ${ }^{1} \cdot$ Ekundayo Peter Mesagan $^{2}$ (D)
}

Received: 14 July 2021 / Accepted: 17 January 2022 / Published online: 22 January 2022

(c) The Author(s), under exclusive licence to Springer-Verlag GmbH Germany, part of Springer Nature 2022

\begin{abstract}
Environmental sustainability and climate change mitigation seem central in the fight against global warming and continuous human sustenance in the twenty-first century. However, non-renewable and renewable energy are at the core of these pollution concerns, particularly among the G20 economies that are the top pollution emitters. Capital investment has been argued to ameliorate or amplify the relationship, unlike other mediators in the energy-pollution nexus. To this end, the study specifically sets out to unravel the mediating role of capital investment in energy-pollution link together with other pollution confounders, including trade openness, foreign direct investment, and energy use for G20 economies over the period 1990-2017. We report vital findings using the pooled mean group estimator and accounting for cross-sectional dependence and heterogeneity among the countries. First, results show that renewable energy negatively impacts carbon emissions in both the short and long runs, while non-renewable energy positively impacts pollution. In addition, the results show that capital investment lowers pollution in the short run but increases it in the long run. Lastly, on interacting capital investment with renewable energy, we find that pollution falls in both the short and long runs, while its interaction with non-renewable energy expands pollution in both periods. On the policy front, since capital investment provides an important channel to reduce pollution in G20 nations, it is therefore recommended that if energy consumption is to work through the capital investment channel to lower pollution in the G20, the proportion of renewable energy must increase relative to non-renewable energy in their energy mix.
\end{abstract}

Keywords Capital investment $\cdot$ Renewable energy $\cdot$ Non-renewable energy $\cdot$ Carbon emissions

JEL Classification Q41 $\cdot \mathrm{Q} 42 \cdot \mathrm{Q} 53 \cdot \mathrm{F} 23 \cdot \mathrm{O} 50$

\section{Introduction}

The rising concerns about environmental sustainability and climate change necessitate the call by the $\mathrm{UNFCCC}^{1}$ for countries to curb global warming. The Paris Agreement and

${ }^{1}$ United Nations Framework Convention on Climate Change. The 2018 edition was held in Katowice, Southern Poland, between the $2^{\text {nd }}$ and $14^{\text {th }}$ November 2018 while the last edition was held in Bonn, Western Germany, between the $17^{\text {th }}$ and $27^{\text {th }}$ June 2019 .

Responsible Editor: Roula Inglesi-Lotz

Ekundayo Peter Mesagan

profdayoms@yahoo.com

Kazeem Bello Ajide

kazeemajide@gmail.com

1 Department of Economics, University of Lagos, Lagos, Nigeria

2 School of Management and Social Sciences, Pan Atlantic University, Lagos, Nigeria other climate agreements chart a new direction for nations to keep warming below 2 , preferably $1.5^{\circ} \mathrm{C}$, compared to pre-industrial levels. Climate change poses an enormous threat to ecosystems, with consequent adverse implications for human livability (Kerr 2007; Yao et al. 2015). The problems involving climate change and environmental pollution often emanate from human consumption of fossil fuels which emit a large amount of carbon emissions. Hence, the environmental consequences of human activities cannot be overemphasised. According to the International Panel on Climate Change (IPCC), about $90 \%$ of climate change is caused by human activities, which remains its main causal factor up until now (IPCC 2015). Moreover, Hughes et al. (2003), Patz et al. (2005), and McMichael et al. (2006) traced the climate change impacts to the greenhouse-gas (GHGs) emissions from human activities. As opined in Yao et al. (2015), from the nineteenth century to date, production activities in developed countries (DCs) account for about 
Fig. 1 Trend of carbon emissions across the major carbon emitters in 2016. Source: Graphed from the underlying data source (Statista 2018)

\section{Trend of Carbon Emissions across the major carbon emitters in 2016}

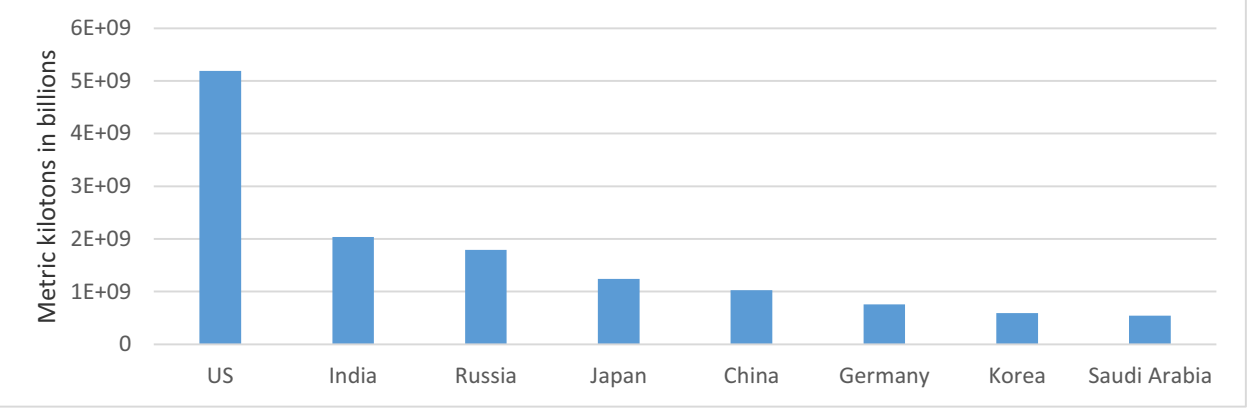

two-thirds of the $\mathrm{CO}_{2}$ emissions from energy consumption. These energy-related $\mathrm{CO}_{2}$ emissions are associated with heavy-duty machines, high-performance vehicles, and other fossil fuels consuming production plants in these countries. Unarguably, most of the GHGs emissions generated globally are attributable to the activities of the G20 economies. Corroborating the preceding claim is Yao et al. (2015), affirming that $\mathrm{G} 20$ countries housed about $67 \%$ of the world's population, produced $86 \%$ of the world's output, and generated $76 \%$ of the world's $\mathrm{CO}_{2}$ emissions in 2010. Similarly, evidence from the International Energy Agency (IEA) suggests that in 2014 , G20 nations accounted for about $85 \%$ of the world economy, two-thirds of the world population, and $75 \%$ of the global trade. They also primarily relied on non-renewable energy, with $77 \%$ of global energy use and accounted for $82 \%$ of the world energy-related $\mathrm{CO}_{2}$ emissions (IEA 2018).

The $\mathrm{G} 20^{2}$ economies, comprising the European Union, twelve emerging nations, and seven developed countries, are notable for high levels of output growth. The considerable success records of these countries in the growth process can arguably be attributed to their massive capital investments. For instance, the United States (US), Germany, Canada, Australia, and Saudi Arabia are heavily industrialised while at the same time contributing significantly to global emissions. In 2016, the USA was credited with the largest $\mathrm{CO}_{2}$ emissions, followed by India, Russia, Japan, China, Germany, Korea, and Saudi Arabia in that order (see Fig. 1).

Moreover, in 2016, fossil fuel energy use per total energy and $\mathrm{CO}_{2}$ emissions correspondingly stood at $85.3 \%$ and 5350.4 million tonnes (MT) for the US, $80.8 \%$ and $760.8 \mathrm{MT}$ for Germany, 63.5\% and 527.4 MT for Canada, and 93.2\% and 408.9 MT for Australia, as well as $99.9 \%$ and 621.8 MT

\footnotetext{
2 The members of the G20 includes the European Union, twelve emerging nations (Indonesia, Brazil, South Africa, South Korea, Russia, China, Turkey, Argentina, Mexico, Saudi Arabia, India, and Australia), and seven developed countries (Italy, Japan, the UK, Canada, France, Germany, and the United States).
}

respectively for Saudi Arabia (BP Statistical Review 2018). Given the fact that energy use causes GHG emissions, as affirmed in Inglesi-Lotz and Dogan (2018), Dogan and Seker (2016), and Mesagan et al. (2019), and capital investments can both mitigate or amplify environmental pollution substances as opined in Blomquist and Cave (2008), Tang and Tan (2015), Mesagan (2015), Zhang and Zhou (2016), and Haider et al. (2019), it calls for a focus on the G20 nations since they are inherently endowed with these two elements.

Given the preceding, we hinge the motivations of this study on the following considerations. First, there have been various commitments since 2009 to end government support for fossil fuels and make "finance flows consistent with a pathway toward low greenhouse gas emissions and climateresilient development" (Paris Agreement, Article 2.1c), yet G20 governments continued to provide significant support to fossil fuels. For instance, International Institute for Sustainable Development (IISD 2020) report states that the G20 governments provided $\$ 584$ billion annually through direct budgetary transfers and tax expenditure, public finance, price support, and state-owned enterprise investment for the production and consumption of fossil fuels at home and abroad. In particular, the governments of these countries provide more support to oil and gas production than any other stage of fossil fuel-related activity, at $\$ 277$ billion (47\% of the total support to fossil fuels). The situation seemed more severe during the COVID-19 outbreak when the G20 countries allocated some $\$ 170$ billion in public money commitments to fossil fuel-intensive.

Second, the G20 economies host $80 \%$ of the world's total installed renewable power generation capacity and hold $75 \%$ of the total global deployment potential of all renewables in the energy sector from 2010 to 2030, as estimated by International Renewable Energy Agency (IRENA). Lastly, capital investments have been argued to constitute about one-quarter of gross global product in monetary terms, thus causing about $30 \%$ of global greenhouse gas emissions 
(Sodersten et al. 2017). Not only that, the entire process of capital investments causes anthropogenic greenhouse gas emissions. These emissions occur at different stages: during construction, use, and end life phase (see Muller et al. (2013) for detailed exposition).

There is undoubtedly extensive empirical literature on the energy-pollution nexus but is mainly mixed. For instance, Stolyarova (2013) and Wang et al. (2013) confirmed that non-renewable energy negatively impacts carbon emissions. However, Soytas et al. (2007), Halicioglu (2009), Zhang and Cheng (2009), Shahbaz et al. (2013), Shafiei and Salim (2014), Cowan et al. (2014), Yao et al. (2015), Bento and Moutinho (2016), Li et al. (2015), Shahsavari and Akbari (2018), Mesagan and Nwachukwu (2018), Inglesi-Lotz and Dogan (2018), Chen et al. (2019), Sharif et al. (2019), Mesagan et al. (2019), and Xian et al. (2019) showed increasing impacts of non-renewable energy consumption on the pollution level. Regarding the channels of pollution transmissions, studies such as Pata (2018), Mesagan and Nwachukwu (2018), Khan et al. (2018), Baloch et al. (2019), Sharif et al. (2019), Charfeddine and Kahia (2019), and Mesagan and Olunkwa (2022) identified financial development routes. Also, studies by Mesagan (2021a, 2021b) and Mesagan et al. (2021) linked environmental problems to the level of financial openness across different countries. While the pollution impact of financial integration is increasing, studies such as Frankel and Rose (2005), Li et al. (2015), Wang et al. (2013), Yao et al. (2015), Pata (2018), Xian et al. (2019), and Haider et al. (2019) then attributed increases in pollution to factors such as urbanization, trade, and population growth.

Specifically, both Frankel and Rose (2005) and Li et al. (2015) attributed trade impact of environmental pollution to polity channel, while Shafiei and Salim (2014), InglesiLotz and Dogan (2018), Chen et al. (2019), and Sharif et al. (2019) provided the pollution-reducing impact of renewable energy channel in the pollution abatement model. Recently, both Ding et al. (2021) and Mesagan (2021b) identified production and consumption activities as the primary causal problems of pollution. While Ding et al. (2021) call for a more carbon-friendly consumption pattern in G-7 countries, Mesagan (2021b) attributes the environmental sustainability problem in Sub-Saharan Africa to its production activities. Again, studies like Mesagan (2021a), Mesagan and Olunkwa (2020), Mesagan et al (2020), and Ajide and Ibrahim (2021) examined how capital investment can enhance pollution control measures. While the studies make a massive foray into the nature of capital investment vis-à-vis fossil fuel energy, they largely ignored the renewable energy impacts in their models. This means that contributions for pollution reduction in these studies would not be comprehensive if the focus is solely on non-renewable energy without considering the impact of the entire energy mix. The present study fills this noticeable gap in the literature.
In the light of the preceding, it is apparent that the debate surrounding the energy-pollution nexus is ongoing and inconclusive. Therefore, the need to re-investigate the nexus for G20 economies pollution and energy nexus via the capital investment channel is salient for these countries as identified in the literature (see Sims et al. 2003; Tang and Tan 2015). This is so as the capital investment can offset the threats of $\mathrm{CO}_{2}$ emissions through the technique effect it creates and can equally amplify it through its embodied carbon content. However, it has received less attention from previous related studies, especially those focusing on G20 nations $^{3}$ that have a massive amount of industrial productivity and carbon pollution. Thus, this paper addresses the energy-pollution problem via the capital investment channel. Examining such a relationship for the G20 economies cannot be overlooked as they are faced with fulfilling their bargain of the Paris Agreement without lowering their productivity amid the persistent increase in $\mathrm{CO}_{2}$ emissions. Consequently, the main objective is to analyse the role of energy in $\mathrm{CO}_{2}$ pollution via the capital investment channel in the $\mathrm{G} 20$. Specifically, the study examines the effect of non-renewable and renewable energy use on environmental pollution. It examines the impact of capital investment on pollution and then analyses the effects of both energy sources on pollution through the capital investment channel. Therefore, our main innovation entails using the capital investment to augment the pollution impacts of renewable and non-renewable energy consumption in G20 nations. Thus, the study extends the frontiers of knowledge in four ways. Firstly, the study disaggregates energy sources into renewable and non-renewable resources to identify the leading cause of pollution in G20 economies in the short run and the long run, and we find non-renewable energy culpable. Secondly, we assess the role of capital investment in the G20's pollution abatement model, in both the short and long runs, and confirm that it is crucial, especially in the short run. Thirdly, we identify capital investment as the augmenting channel for reducing G20's pollution resulting from non-renewable energy, but with the condition that the share of renewable energy rises in the mix. Lastly, we employ heterogeneous and dynamic panel analysis to generate panel estimates for the short and long runs. Our subsequent findings consider cross-sectional dependence, having confirmed that G20 nations are dependent cross-sectionally and have heterogeneous features also.

The balance of the paper is as follows: section "Facts on alternative energy use and carbon pollution in G20 economies" presents the facts on alternative energy usage and carbon pollution in G20; section "Research methodology" dwells on the research methodology; section "Results and

\footnotetext{
${ }^{3}$ With the exception of Ajide and Ibrahim (2021) that investigated the threshold effects of capital investments on carbon emissions in G20 economies.
} 
Table 1 Energy use by fuel type and carbon pollution in G20 countries

\begin{tabular}{|c|c|c|c|c|c|c|}
\hline \multirow[t]{3}{*}{ Countries } & \multicolumn{4}{|c|}{ Energy consumption (\% of total) } & \multirow{2}{*}{\multicolumn{2}{|c|}{$\begin{array}{l}\mathrm{CO}_{2} \text { emissions } \\
\text { (million tonnes) }\end{array}$}} \\
\hline & \multirow{2}{*}{$\begin{array}{l}\text { Fossil fuels } \\
2015\end{array}$} & \multirow[t]{2}{*}{ Renewables } & \multirow{2}{*}{$\begin{array}{l}\text { fossil fuels } \\
2016\end{array}$} & \multirow[t]{2}{*}{$\overline{\text { Renewables }}$} & & \\
\hline & & & & & 2015 & 2016 \\
\hline Italy & 83.5 & 16.5 & 84.0 & 16.0 & 336.2 & 336.9 \\
\hline Japan & 92.2 & 7.8 & 90.8 & 9.2 & 1206.6 & 1191.2 \\
\hline UK & 81.8 & 18.2 & 81.4 & 18.6 & 433.4 & 406.4 \\
\hline Canada & 64.4 & 35.6 & 63.5 & 36.5 & 531.6 & 527.4 \\
\hline France & 50.3 & 49.7 & 52.1 & 47.9 & 309.7 & 316.0 \\
\hline Germany & 80.1 & 19.9 & 80.8 & 19.2 & 751.1 & 760.8 \\
\hline United States & 86.1 & 13.9 & 85.3 & 14.7 & 5445.0 & 5350.4 \\
\hline Indonesia & 96.7 & 3.3 & 96.7 & 3.3 & 492.5 & 531.4 \\
\hline Brazil & 66.7 & 33.3 & 63.2 & 36.8 & 491.3 & 458 \\
\hline Saudi Arabia & 99.96 & 0.04 & 99.96 & 0.04 & 611.7 & 621.8 \\
\hline Australia & 94.3 & 5.7 & 93.2 & 6.8 & 413.6 & 408.9 \\
\hline Russia & 87.9 & 12.1 & 87.2 & 12.8 & 1521.9 & 1490.1 \\
\hline South Korea & 85.2 & 14.8 & 85.5 & 14.5 & 654.0 & 662.1 \\
\hline India & 92.5 & 7.5 & 92.5 & 7.5 & 2157.4 & 2271.1 \\
\hline Turkey & 85.5 & 14.5 & 85.2 & 14.8 & 343.0 & 361.0 \\
\hline China & 88.2 & 11.8 & 87.0 & 13.0 & 9164.5 & 9123 \\
\hline Argentina & 86.8 & 13.2 & 87.3 & 12.7 & 193.4 & 194.3 \\
\hline Mexico & 93.0 & 7.0 & 92.9 & 7.1 & 481.4 & 470.3 \\
\hline South Africa & 96.5 & 3.5 & 95.3 & 4.7 & 421.8 & 425.7 \\
\hline EU & 75.1 & 24.9 & 75.4 & 24.6 & 3477.0 & 3485.1 \\
\hline
\end{tabular}

Compiled from the BP Statistical Review (BPS 2018) discussion" discusses the result; and section "Conclusion" concludes with policy implications and future outlook.

\section{Facts on alternative energy use and carbon pollution in $\mathbf{G} 20$ economies}

\section{Carbon emission and energy usage by types of fuel}

Table 1 presents the relationship between energy consumption by fuel types and $\mathrm{CO}_{2}$ emissions in $\mathrm{G} 20$ economies. For most countries within the G20, available evidence shows a direct and positive link between fossil fuel energy consumption and pollution.

As shown in Table 1, in 2015, Brazil consumed 66.7\% of fossil fuel energy and $33.3 \%$ of renewable energy, but in 2016, it increased its consumption of renewable energy to $36.8 \%$ and was able to lower its $\mathrm{CO}_{2}$ emissions to 458 from 491.3 MT in 2015. The increase in biofuels on a large scale enables Brazil to reduce carbon emissions significantly. Between 2015 and 2016, Russia increased its renewable energy use from 12.1 to $12.8 \%$, while its $\mathrm{CO}_{2}$ emissions correspondingly reduced to $1490 \mathrm{MT}$ from the initial 1521.9 MT. Both China and the UK marginally increased their renewable energy consumption from 11.8 to $13.0 \%$ and 18.2 to $18.6 \%$, respectively. As a result, both countries reduced their $\mathrm{CO}_{2}$ emissions between 2015 and 2016 from 9164 to $9123 \mathrm{MT}$ and from 433.4 to $406.4 \mathrm{MT}$, respectively. Similarly, Italy increased its fossil energy use marginally from 83.5 to $84.0 \%$ between 2015 and 2016, and its $\mathrm{CO}_{2}$ emissions rose marginally from 336.2 to 336.9 MT. Unlike others, Japan's increase in renewable energy use from 7.8 to $9.2 \%$ led to a significant drop in carbon emissions from 1206.6 to 1191.2 MT over the same period.

In France, the country generated substantial energy from renewable sources. However, as depicted in Table 1, increasing fossil fuel energy from 50.3 to $52.1 \%$ causes $\mathrm{CO}_{2}$ emissions to significantly increase from 309.7 to $316.0 \mathrm{MT}$ between 2015 and 2016. The United States follow similar trends as its $\mathrm{CO}_{2}$ emissions dropped from 5445 to 5350 MT as fossil fuel energy fell from 86.1 to $85.3 \%$ during the same period. The $\mathrm{CO}_{2}$ emissions dropped for other $\mathrm{G} 20$ economies because they reduced their fossil fuel energy consumption. These countries include Mexico, Australia, and Canada. However, South Africa marginally increased renewable energy use from $3.5 \%$ in 2015 to $4.7 \%$ in 2016 , and the country recorded a slight increase in $\mathrm{CO}_{2}$ emissions to 425.8 MT from the initial 421.7 MT. On the other hand, India's $\mathrm{CO}_{2}$ emissions rose to 2271.1 from 2157.4 MT between 2015 and 2016 despite maintaining the same ratio 


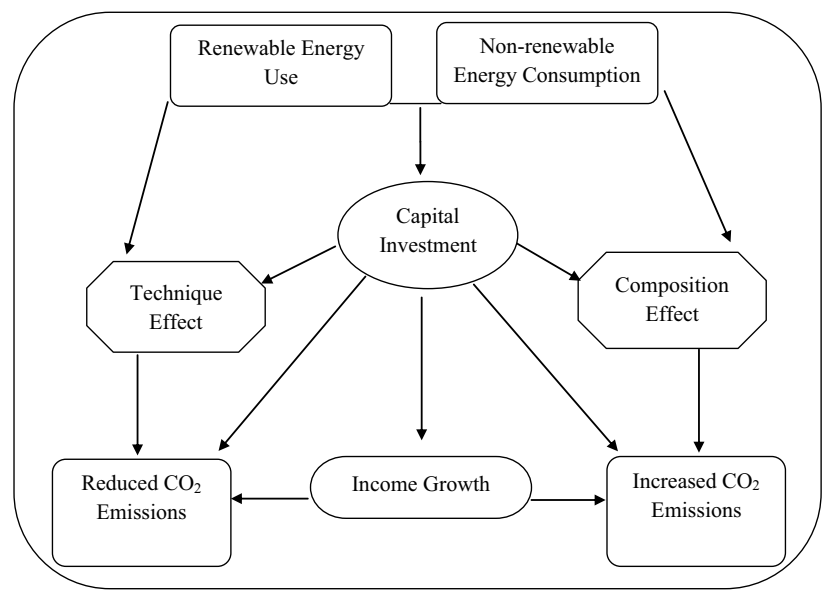

Fig. 2 The role of capital investment in environmental quality. Source: Authors' computation

of $7.5 \%$ in renewable energy use. Also, the EU increased non-renewable energy use from 75.1 to $75.4 \%$, while its $\mathrm{CO}_{2}$ emissions increased from 3477 to 3485.1 MT for both years. Moreover, other G20 economies that witnessed a one-toone increase in non-renewable energy and $\mathrm{CO}_{2}$ emissions are Argentina, South Korea, and Germany. Then, Indonesia, Saudi Arabia, and India maintained the same ratio of fossil energy use for the two years and recorded an increase in their $\mathrm{CO}_{2}$ emissions.

\section{The link between fossil fuel energy use and environmental quality}

The framework presented in Fig. 2 depicts the mediating role of capital investment in $\mathrm{CO}_{2}$ emissions for the $\mathrm{G} 20$ nations. In addition, Fig. 2 graphically illustrates how renewable and non-renewable energy use can curtail and increase carbon emissions among the G20 countries. From the figure, the amount of renewable and non-renewable energies in the energy mix will likely alter the situation of $\mathrm{CO}_{2}$ emissions in G20 economies. For instance, experience has shown that if the energy mix contains more fossil fuel energy, the volume of emissions of carbon would increase and vice versa (see Dogan and Seker 2016; Mesagan et al. 2019; Chen et al. 2019).

Contrariwise, $\mathrm{CO}_{2}$ emissions can be lowered when companies use low carbon-emitting machines during production activities or generate energy from renewable sources. As suggested in Mesagan et al. (2019), the attraction of appropriate production technologies is beneficial for countries to lower $\mathrm{CO}_{2}$ emissions.

Moreover, Fig. 2 supports the notion that capital investment inflow helps increase output growth in G20, which can negatively or positively affect their environmental quality (Safdari et al. 2013; Bernard et al. 2004). To substantiate this, Eregha and Mesagan (2017) affirmed that energy consumption enhances output growth, and Bernard et al. (2004) opined that investment and output growth reduce environmental damage, while Safdari et al. (2013) revealed that increased income and investment worsened environmental degradation. Also, the Environmental Kuznets Curve (EKC) suggested the existence of a reversed U-shaped association between income and emission levels (see Andreoni and Levinson 2001; Stern 2004). This informs the double-barrel effect of income on carbon pollution in Fig. 2. Bernard et al. (2004) affirmed that with solid regulations, countries would attract only environmentally friendly capital investments to generate the technique effect that will lower $\mathrm{CO}_{2}$ emissions. However, when highly carbon-laden plants are drawn, the composition effect of emissions is expected to increase, and $\mathrm{CO}_{2}$ emissions would also increase. Therefore, capital investment can provide the appropriate channel for G20 economies to lessen $\mathrm{CO}_{2}$ emissions to achieve their respective Paris Agreement goals.

\section{Dissecting the plans for curbing carbon emissions in $\mathbf{G} 20$ economies}

According to Wilson (2014), energy usage and pollution in China increased significantly from the early 2000s, making it overtake the US in 2007 as the country with the most considerable amount of carbon emissions globally. In 2002, $\mathrm{CO}_{2}$ emission in China was about half lesser than the $\mathrm{CO}_{2}$ emissions in America. However, by 2012, its $\mathrm{CO}_{2}$ emission had doubled that in America and surpassed emissions generated in the EU. Over the period, the Chinese authorities developed a short-term energy-intensity reduction target, which covers between 2006 and 2010 to reduce the country's $\mathrm{CO}_{2}$ emissions and energy intensity. Furthermore, China established another long-term $\mathrm{CO}_{2}$ emissions reduction target for 2020 (Zhou et al. 2011). Besides, the industrial sector in China contributed over 50\% of its energy utilised (Grubb et al. 2015). According to the Australian Government's Department of Environment and Energy (DEE 2017), Australia is among the 178 countries with less than $2 \%$ of emissions but jointly contributes about $40 \%$ of total emissions globally. Having ratified the first commitment of the Kyoto Protocol, the country reduced emissions by 128 MT between 2008 and 2012. The implication is that the country is well ahead of achieving its 2030 emissions reduction target between 26 and $28 \%$ below the 2005 level. However, Climate Action Tracker (CAT 2019) opined that based on total country-wide emissions and lack of accelerated climate action policies, Australia might substantially increase its GHGs emissions between 8 and $16 \%$ above 2005 levels by 2030 . 
Similarly, Mazumdaru (2017) reported that India's $\mathrm{CO}_{2}$ emission per person was about $33 \%$ of the global average owing to its energy sector's $60 \%$ dependence on coal. However, the country's emission is lesser than that of China and the US. Moreover, in terms of total GHG emissions, India follows directly behind China, the United States, and the EU with about $4.5 \%$ of GHG concentrations. The high pace of industrial production increased the country's non-renewable energy consumption. Hence, to lower GHG emissions to between 33 and $35 \%$ of GDP by 2030, the country plans to diversify its energy mix. This will enable India to generate about 175 gigawatts (GW) from renewable sources like solar by 2022 and increase its renewable energy up to $40 \%$ of total energy by 2030 . At the turn of 2030, India will only permit battery-driven and electric vehicles (Mazumdaru 2017; CAT 2019). In 2016, Canada announced its clean growth and climate framework with measures to ease out old coal plants and establish a carbon pricing plan. The Canadian NDC goal for 2030 is to lower emissions by about $30 \%$ below its 2005 level (CAT 2019). However, the climate action tracker opines that Canada may find it challenging in achieving its 2030 Paris Agreement target unless it depends on carbon sinks in the wetlands, forests, and soils, while also sacrificing its growth target.

Moreover, Russia has always experienced a considerable increase in foreign exchange earnings due to the rise in world crude oil prices of the early 2000s. As a result, it is one of the largest carbon-emitting nations in the whole world. Climate Action Tracker (2019) reports that Russia set up a national policy on climate change to reduce emission intensity. Although its Intended Nationally Determined Contribution's (INDC) target for reducing pollution exceeds the Paris Agreement's level, it is still among the weakest by any country. Hence, it may affect the country's quest to lower carbon emissions by 2030 to below $70 \%$ of levels in 1990. According to Kuramochi (2014), the Japanese government has redesigned its energy policy for combating climate change after the March 2011 Fukushima nuclear disaster. To this end, in 2013, the country sets up a new emissions reduction target of $3.8 \%$ from the 2005 level to replace the earlier 25\% targeted reduction from the 1990 standard set in Copenhagen in 2009. However, CAT (2019) opined that the plan of the country to construct coal plants could be risky to the climate change mitigation efforts of the Japanese government. Furthermore, the ability of the country to build new nuclear reactors could also prove crucial in achieving its 2030 emissions reduction target.

The Brazilian government employs different strategies to reduce emissions and improve global warming. The country produces biofuel, most especially ethanol, to diversify its energy sources and lower pollution (Masiero 2011). To increase its renewable energy mix and reduce emissions, the country established plants to produce ethanol-driven vehicles on a large scale in 1979. However, the current deforestation in the country since 2016, coupled with the government's reduction of finances by half to its Environment Ministry, increased the country's emission for the current period (CAT 2019). For the United States, CAT (2019) reported that wind and solar rose significantly in contribution while about $6.3 \mathrm{GW}$ of coalfiring plants shut down in 2017. The resultant effect of this effort is that fossil fuel energy dropped for the first time in 2017 in the US since the global financial crisis of 2008. While decarbonizing the US and limiting global warming to $20 \mathrm{C}$ were largely unrealistic due to the threat from Donald Trump's administration to remove the country from the Agreement, the recent efforts and support from the new US President, Joe Biden, could offer a significant turnaround in achieving the country's decarbonization target.

The German government announced 'Energiewende', an ambitious energy transition plan to decarbonise the economy in 2010. With Energiewende, the country aims to lower GHG emissions by $40 \%$ below 1990 levels by 2020, which is more ruthless than the European Union's 20\% targeted reduction by 2020 and a further $40 \%$ below 1990 levels by 2030 (Hope 2014; Appunn 2018). Furthermore, another 95\% emissions reduction target below 1990 levels is set for 2050 in the plan. Moreover, the country plans to increase its renewable energy by about $60 \%$ and make renewable energy contribute over two-thirds of its energy consumption in 2050 (Appunn 2018). One major challenge with the German plan for 2020 emissions reduction is that the country still requires some conventional power source, like coal, to run with its renewables. Hence, phasing out its nuclear power might not be realistic in 2020. For South Africa, the country established an Integrated Resource Electricity Plan (IRP) to increase its renewable energy for 2030 (CAT 2019). The robust renewable energy target that IRP set to be achieved in 2030 is 17.8 GW. Also, between 2025 and 2030, the country's Nationally Determined Contribution (NDC) has targeted reducing emissions to between 398 and 614 MT. The Climate Action Tracker (2019) noted that economic recession, which slows the pace of economic growth, and the current national policies, might enhance its quest to achieve its set 2030 targets. However, the recent transition in government that stalled the signing of the power purchase agreement with renewable energy firms, the uncertainty in the starting date to levy $\mathrm{CO}_{2}$ pollution tax, and the expected rise in the number of coal plants currently under construction might hinder its 2030 climate change target (CAT 2019; Mesagan et al. 2019).

\section{Research methodology}

This study leans on the proposition of the EKC that posits a long-run beneficial link between pollution and income. Thus, following the models specified in Andreoni and 
Levinson (2001), Stern (2004), and Mesagan et al (2020), we define the model between $\mathrm{CO}_{2}$ emissions and income, together with other drivers like energy use, trade openness, and foreign direct investment while accounting for capital investment as a mediating variable. Thus, we specify the model in an empirical estimation form as: approach. The framework was developed by Pesaran et al. (1999) for handling heterogeneous samples. The PMG is more appropriate because of its capability to analyse cross-country studies with many cross sections $(N)$ and large series $(T)$. Hence, the PMG is preferred over the GMM framework that can only accommodate large $N$ and small $T$ dimensions (see Pesaran and Smith 1995; Pesaran et al. 1999).

$C O_{2}=\alpha_{0}+\alpha_{1} Y+\alpha_{2} Y^{2}+\alpha_{3} R E N+\alpha_{4} N E N+\alpha_{5} C I+\alpha_{6} F D I+\alpha_{7} \boldsymbol{T O}+\varepsilon$

Where $\mathrm{CO}_{2}$ is carbon emission per capita; $Y$ is the per capita gross domestic product; $Y^{2}$ is square of GDP per capita; REN is renewable energy consumption; NEN is nonrenewable energy consumption; $\mathrm{CI}$ is capital investment; FDI is foreign direct investment; and TO stands for trade openness respectively. Also, $\alpha_{0}$ is the intercept, $\alpha_{1}$ to $\alpha_{7}$ are the various parameter estimates while $\varepsilon$ is the residual term.

To capture the effect of renewable and non-renewable energy on pollution, we modify Eq. (1) as:

$\mathrm{CO}_{2}=\alpha_{0}+\alpha_{1} Y+\alpha_{2} Y^{2}+\alpha_{3} R E N+\alpha_{4} N E N+\alpha_{5} F D I+\alpha_{6} T \boldsymbol{O O}+\varepsilon$

In Eq. (2), all the variables remained as earlier explained while $\alpha_{0}$ remains the intercept, $\alpha_{1}$ to $\alpha_{6}$ are the various parameter estimates, $\varepsilon$ is the white noise error term, and both FDI and TO are used as control variables in the model.

After this, we present Eq. (3) to determine the specific impact of capital investment on pollution in $\mathrm{G} 20$ as:

$\mathrm{CO}_{2}=\alpha_{0}+\alpha_{1} Y+\alpha_{2} Y^{2}+\alpha_{3} C I+\alpha_{4} F D I+\alpha_{5} \boldsymbol{T O}+\varepsilon$

Where all the variables remained as earlier explained while $\alpha_{0}$ remains the intercept, $\alpha_{1}$ to $\alpha_{5}$ are the parameter estimates, $\varepsilon$ is the white noise error term, and CI is capital investment.

Lastly, we present Eq. (4) to capture the conditioning impact of renewable and non-renewable energy on pollution via the capital investment channel as:
Thus, given the panel ARDL model in Eq. (1):

$a_{i}(L) y_{i t}=b_{i}(L) x_{i t}+d_{i} z_{i t}+\varepsilon_{i t}$

Where $a_{i}(L) y_{i t}$ represents the vector of regressed variables, $b_{i}(L) x_{i t}$ captures the lagged dependent variable, $d_{i} z_{i t}$ stands for the vector of covariate regressors, $\varepsilon$ is the residual term, and both $i$ and $t$ represent the cross section and time series respectively. Then, for country $i$, where $i=1, \ldots, N$, the long-run estimate is represented as $\phi_{i}=\frac{b_{i}(1)}{d_{i}(1)}$.

For the Pooled Mean Group approach, the shortrun parameters are varied across samples while long-run estimates remain similar across the sample. Therefore, the unrestricted PMG condition for country $i=1,2 \ldots, N$, and period $t=1,2 \ldots, T$ for the dependent variable $y$ becomes:

$y_{i t}=\sum_{j=1}^{q} \omega_{i j} y_{i, t-j}+\sum_{j=0}^{\rho} \gamma_{i j}^{\prime} x_{i, t-j}+\mu_{i}+\varepsilon_{i t}$

Where, $x_{i j}=k x 1$ vector of regressors for panel $i$ and $\mu_{i}=$ fixed effects. We then represent Eq. (6) in a VECM structure using a process of re-parameterisation as:

$\Delta y_{i t}=\phi_{i}\left(y_{i, t-1}-\varphi_{i}^{\prime} x_{i, t-1}\right)+\sum_{j=1}^{q-1} \omega_{i j} \Delta y_{i, t-j}+\sum_{j=0}^{\rho-1} \gamma_{i j}^{\prime} x_{i, t-j}+\mu_{i}+\varepsilon_{i t}$

Where, $\Delta_{i}$ 's are difference operators, $\phi_{i}$ 's are the error cor-

$\mathrm{CO}_{2}=\alpha_{0}+\alpha_{1} Y+\alpha_{2} Y^{2}+\alpha_{3}$ RENCI $+\alpha_{4} \mathrm{NENCI}+\alpha_{5} F D I+\alpha_{6} \mathrm{TO}+\varepsilon$

In Eq. (4), all the variables remained as earlier explained while RENCI captures the interaction between renewable energy and capital investment and NENCI proxies the interaction between non-renewable energy and capital investment. Also, $\alpha_{0}$ is the intercept, $\alpha_{1}$ to $\alpha_{6}$ are the parameter estimates, and $\varepsilon$ is the residual term, while FDI and TO are used as control variables.

In this study, using capital investment as a pollution reduction channel is vital owing to the technique effect that environmentally friendly technologies generate. Even when energy use is emission-laden, capital investment can make the technique effect to neutralise the threats of $\mathrm{CO}_{2}$ emissions as suggested by the pollution halo theory. Therefore, the empirical model is analysed using the Pooled Mean Group (PMG) rection estimates, and $\varphi_{i}$ 's represent the long-run estimates. Furthermore, the short-run estimates, intercepts, and adjustment speeds vary across samples in this framework, whereas long-run estimates are similar for the panel (see Eregha and Mesagan 2020). Moreover, we use both the homogeneous and heterogeneous panel unit root tests (PURT), whereas the Friedman Cross-sectional Dependence (CD) test, Frees' test, and Breusch-Pagan LM test of Pesaran and Chudik (2014) are employed to establish the existence of $\mathrm{CD}$ among the sample of countries. We then use the Pesaran CD test to determine the appropriateness of the 1st-generation PURT. Also, we confirm cointegration among the regressors using Westerlund (2007) by bootstrapping the critical values since CD exists. 
The variables used based on Andreoni and Levinson (2001), Stern (2004), Dasgupta et al. (2002), and Mesagan et al. (2018) include carbon emissions per person $\left(\mathrm{CO}_{2}\right)$, non-renewable energy use per capita (NEN) measured in kilowatts, renewable energy per person (REN) denoted in kilowatts, real GDP per head (Y), and capital investment (CI) proxied with gross fixed capital formation to GDP. Others include the interactions of non-renewable energy use and capital investment (NENCI) and that between renewable energy use and capital investment (RENCI). The last variables include trade openness (TO) and foreign direct investment (FDI) of the G20 nations. We sourced data spanning 1990-2017 from the Global Carbon Atlas (2018) and World Bank's World Development Indicators (WDI 2019). The summary of the parameter chosen, and their respective measurement, is presented in Table 2. For the empirical implementation of the preceding models and data analyses, this study employs STATA 16 version owing to its flexibility and sophistication.

\section{Results and discussion}

\section{Results}

In Table 3, we present the correlation matrix to confirm the possibility of multicollinearity problem among the regressors. Given that regression spuriousness is often caused by perfect collinearity among or between variables of interest, Table 3 suggests a weak correlation, thus confirming the suitability of the estimated models.

The cross-sectional dependence (CD) tests make it possible to ascertain if the panel data exhibit $\mathrm{CD}$ among the variables. $\mathrm{CD}$ in panel data is caused by standard shocks and unexplained elements that are fused into the residual terms. As explained in the methodology section, we also use the CD tests to check the appropriateness of the first-generation panel stationarity tests. They include the Breusch-Pagan Langrage Multiplier (LM), the Pesaran $\mathrm{CD}$, the Friedman chi-square, and the Frees normality test. Table 4 shows that we can reject the hypothesis of no CD in the panel data since the Friedman, Pesaran, and Breusch-Pagan tests are significant at $1 \%$ levels. This is also confirmed by the Frees statistics of $4.727,4.561$, and 4.404 in models I-III since they exceed the Frees' Q distribution critical values at $1 \%, 5 \%$, and $10 \%$. It implies that the Frees test is also significant at $1 \%$. Even in model III, where only the Pesaran CD is insignificant, we strongly confirm $\mathrm{CD}$. The implication is that we confirm the existence of strong CD among the G20 countries because most of the measures reject the main hypotheses. Hence, the use of 1st-generation PURT is inadequate. We then present the 2nd-generation PURT test, which accounts for

Table 2 Regressors used in the study

\begin{tabular}{llll}
\hline Regressors & Meaning & Measurement & Sources \\
\hline $\mathrm{CO}_{2}$ & Carbon emissions per person & Measured as metric tons per capita & $\begin{array}{c}\text { Global Car- } \\
\text { bon Atlas } \\
(2018)\end{array}$ \\
NEN & Non-renewable energy use & Measured in kilowatts per capita & WDI (2019) \\
REN & Renewable energy use & Measured in kilowatts per capita & WDI (2019) \\
Y & Real GDP per head & Measures as per capita income in US dollars & WDI (2019) \\
CI & Capital investment & Measures as gross fixed capital formation per GDP & WDI (2019) \\
TO & Trade openness & Measures as total trade per GDP & WDI (2019) \\
FDI & Foreign direct investment & Measured as the net inflow of foreign investment & WDI (2019) \\
NENCI & Non-renewable energy-capital investment Interaction & Interaction term & Derived \\
RENCI & Renewable energy-capital investment Interaction & Interaction term & Derived \\
\hline
\end{tabular}

Authors' compilation

Table 3 Correlation of variables

\begin{tabular}{|c|c|c|c|c|c|c|c|}
\hline & REN & $\mathrm{CO}_{2}$ & $N E N$ & $C I$ & $Y$ & TO & $F D I$ \\
\hline REN & 1.0000 & & & & & & \\
\hline $\mathrm{CO}_{2}$ & -0.5997 & 1.0000 & & & & & \\
\hline NEN & -0.5188 & 0.4861 & 1.0000 & & & & \\
\hline$C I$ & 0.1158 & -0.1081 & -0.0285 & 1.0000 & & & \\
\hline$Y$ & -0.4847 & 0.5891 & 0.1131 & -0.1966 & 1.0000 & & \\
\hline TO & -0.2615 & 0.2109 & 0.1763 & 0.0428 & 0.0602 & 1.0000 & \\
\hline$F D I$ & -0.0126 & 0.0511 & 0.0253 & 0.0296 & 0.0746 & 0.1153 & 1.0000 \\
\hline
\end{tabular}

Authors' compilation 
Table 4 CD test results

\begin{tabular}{|c|c|c|c|c|c|c|}
\hline \multicolumn{7}{|c|}{ Null hypothesis: There is no CD among selected nations } \\
\hline \multirow[t]{2}{*}{ Tests } & \multicolumn{2}{|l|}{ I } & \multicolumn{2}{|l|}{ II } & \multicolumn{2}{|l|}{ III } \\
\hline & Statistic & Prob. & Statistic & Prob. & Statistic & Prob. \\
\hline Breusch-Pagan LM test & 1535.404 & $0.0000 * * *$ & 1498.577 & $0.0000 * * *$ & 1442.965 & $0.0067 * * *$ \\
\hline Pesaran CD test & 2.607 & $0.0091 * * *$ & 2.066 & $0.0388 * *$ & 1.577 & 0.1147 \\
\hline Friedman test & 39.862 & $0.0022 * * *$ & 30.894 & $0.0296 * *$ & 29.442 & $0.0432 * *$ \\
\hline Frees test & $4.727 * * *$ & & $4.561 * * *$ & & $4.404 * * *$ & \\
\hline \multirow[t]{3}{*}{ Frees' Q distribution } & 0.0924 & $10 \%$ & 0.0924 & $10 \%$ & 0.0924 & $10 \%$ \\
\hline & 0.1204 & $5 \%$ & 0.1204 & $5 \%$ & 0.1204 & $5 \%$ \\
\hline & 0.1726 & $1 \%$ & 0.1726 & $1 \%$ & 0.1726 & $1 \%$ \\
\hline
\end{tabular}

$* * *, * *$ Indicate $1 \%, 5 \%$ critical levels

CD (Pesaran 2007). The Pesaran (2007) test is robust for CD by cross-sectionally augmenting the IPS statistic of Im et al. (2003). Next is to compare the cross-sectionally augmented IPS (CIPS) statistic with the cross-sectionally augmented Dickey-Fuller distribution (CADF) critical values at various levels.

Table 5 displays the 1st-generation panel unit test from the homogeneous and heterogeneous processes. Table 5 suggests that considering the homogeneous tests with Breitung (2001) and Levin et al. (2002), only foreign direct investment is stationary at levels, while every other independent variable is not stationary. Similarly, using the heterogeneous tests with ADF Fisher and Im et al. (2003), only capital investment, FDI, and NENCI are stationary at levels, while renewable energy, $\mathrm{NEN}, \mathrm{CO}_{2}$, income, trade, and renewable energy-capital investment interaction term are not stationary at levels. Nevertheless, when the panel data are first differenced, all the variables become stationary. So, testing at $5 \%$ and $1 \%$ significance levels, the null hypothesis of unit root is rejected, and we confirm the stationarity of all the variables among the G20 nations. Then, 2nd-generation PURT result based on Pesaran (2007) is presented in Table 6.

Table 6 shows that capital investment, foreign direct investment, and non-renewable energy-capital investment interaction are stationary at levels, while renewable energy, $\mathrm{CO}_{2}$, NEN, income per capita, trade, and the renewable energy-capital investment interaction term are stationary when first differenced. Therefore, testing at $5 \%$ and $1 \%$ levels, the hypothesis of homogeneous unit root is rejected. At the same time, stationarity is confirmed for all variables among the G20 nations.

Table 7 presents the Westerlund (2007) panel cointegration test, which appropriately measures long-run relationships in heterogeneous panels. As shown in Table 7, we conduct the cointegration test by bootstrapping the critical values since there is cross-sectional dependence. The optimal lag lengths and leads are chosen using the Akaike

Table $51^{\text {st }}$-Generation PURT

\begin{tabular}{|c|c|c|c|c|c|c|c|c|}
\hline \multirow[t]{3}{*}{ Variables } & \multicolumn{4}{|c|}{ Similar unit root processes } & \multicolumn{4}{|c|}{ Varied unit root processes } \\
\hline & \multicolumn{2}{|l|}{ @ Levels } & \multicolumn{2}{|c|}{ @ First differences } & \multicolumn{2}{|l|}{ @ Levels } & \multicolumn{2}{|c|}{ @ First differences } \\
\hline & $\begin{array}{l}\text { Levin et al. } \\
\text { (2002) }\end{array}$ & Breitung (2001) & $\begin{array}{l}\text { Levin et al. } \\
(2002)\end{array}$ & Breitung (2001) & Im et al. (2003) & ADF-Fisher & Im et al. (2003) & ADF-Fisher \\
\hline$R E N$ & -2.8002 & 5.5726 & $-16.642 * * *$ & $-9.8403 * * *$ & -0.9002 & 34.386 & $-4.9099 * * *$ & $419.609 * * *$ \\
\hline $\mathrm{CO}_{2}$ & -2.4754 & 4.6722 & $-10.009 * * *$ & $-4.5689 * * *$ & -1.0235 & 49.305 & $-4.8823 * * *$ & $414.186^{* * *}$ \\
\hline$N E N$ & $-5.1175 * * *$ & 3.8829 & $-15.798 * * *$ & $-10.829 * * *$ & -1.3668 & 36.262 & $-5.2705 * * *$ & $480.252 * * *$ \\
\hline$C I$ & $-8.9004 * * *$ & -0.2750 & $-16.287 * * *$ & $-6.7620 * * *$ & $-2.0285^{* *}$ & $72.254 * *$ & $-4.2840 * * *$ & $307.880 * * *$ \\
\hline$Y$ & -0.8709 & 10.2652 & $-10.221 * * *$ & $-3.8031 * * *$ & 0.5595 & 8.8073 & $-3.8757 * * *$ & $264.758 * * *$ \\
\hline TO & $-6.6535^{* *}$ & 0.1091 & $-21.287 * * *$ & $-12.972 * * *$ & -1.6483 & 48.379 & $-5.1928 * * *$ & $457.387 * * *$ \\
\hline$F D I$ & $-10.719 * * *$ & $-5.6502 * * *$ & $-19.873 * * *$ & $-14.985 * * *$ & $-2.9402 * * *$ & $147.389 * * *$ & $-6.1364 * * *$ & $633.439 * * *$ \\
\hline RENCI & -2.7963 & 2.4965 & $-17.255^{* * *}$ & $-8.1856^{* * *}$ & -1.0650 & 40.920 & $-4.6872 * * *$ & $368.067 * * *$ \\
\hline NENCI & $-8.6538 * * *$ & 0.4703 & $-16.042 * * *$ & $-6.6518 * * *$ & $-1.9306^{* *}$ & $66.138 * * *$ & $-4.2645^{* * *}$ & $305.148 * * *$ \\
\hline
\end{tabular}

**, *** mean $5 \%, 1 \%$ critical levels 
Table $62^{\text {nd }}$-Generation PURT based on Pesaran (2007)

\begin{tabular}{|c|c|c|c|c|c|c|}
\hline \multirow[t]{2}{*}{ Regressors } & \multirow{2}{*}{$\begin{array}{l}\text { CIPS statistic@ } \\
\text { Level }\end{array}$} & \multirow{2}{*}{$\begin{array}{l}\text { CIPS statistic @ } \\
1^{\text {st }} \text { difference }\end{array}$} & \multicolumn{3}{|c|}{ CADF critical values } & \multirow[t]{2}{*}{ Stationarity decision } \\
\hline & & & $10 \%$ & $5 \%$ & $1 \%$ & \\
\hline$R E N$ & -1.761 & $-4.815^{* * *}$ & -2.11 & -2.2 & -2.38 & $1^{\text {st }}$ difference \\
\hline $\mathrm{CO}_{2}$ & -1.467 & $-4.535 * * *$ & -2.11 & -2.2 & -2.38 & $1^{\text {st }}$ difference \\
\hline$N E N$ & -1.863 & $-4.881 * * *$ & -2.11 & -2.2 & -2.38 & $1^{\text {st }}$ difference \\
\hline$C I$ & $-2.330 * *$ & $-4.255^{* * *}$ & -2.11 & -2.2 & -2.38 & Level \\
\hline$Y$ & -1.210 & $-3.365 * * *$ & -2.11 & -2.2 & -2.38 & $1^{\text {st }}$ difference \\
\hline TO & -2.028 & $-4.412 * * *$ & -2.11 & -2.2 & -2.38 & $1^{\text {st }}$ difference \\
\hline$F D I$ & $-3.336 * * *$ & $-5.583 * * *$ & -2.11 & -2.2 & -2.38 & Level \\
\hline RENCI & -1.123 & $-4.621 * * *$ & -2.11 & -2.2 & -2.38 & $1^{\text {st }}$ difference \\
\hline$N E N C I$ & $-2.417 * * *$ & $-4.266 * * *$ & -2.11 & -2.2 & -2.38 & level \\
\hline
\end{tabular}

$* * *$ and $* *$ indicate $1 \%$ and $5 \%$ level of significance information criterion (AIC). We reject the null hypothesis of no cointegration from the table at $1 \%$ and confirm the existence of a long-run association among the regressors.

Tables 8 and 9 present the empirical results. The panel short-run result is shown in Table 8, while Table 9 displays the long-run panel results. Three models are presented using the PMG. 'Model I' is estimated without the interaction terms and capital investment, and 'Model II' is presented by controlling for capital investment but without the interaction terms. In 'Model III', we estimate only the interaction terms and control variables while excluding REN, NEN, and capital investment. This helps remove the possible effect of multicollinearity between RENCI, CI, and REN, on the one hand, and between NENCI, CI, and NEN on the other hand. Also, the stepwise regression makes it possible to ascertain the crucial role of capital investment in the pollution abatement model of the G20 economies.

The short-run results in Table 8 show that renewable energy use negatively impacts carbon emissions while keeping all the other explanatory variables in models I and II constant. This suggests that renewable energy lowers the amount of pollution in G20. For non-renewable energy, it is evident in Table 8 that it positively affects pollutions. The implication is that while keeping all other variables constant, non-renewable energy consumption enhances shortterm emissions in G20. Considering the capital investment result, Table 8 shows its negative impacts on $\mathrm{CO}_{2}$ emissions. Suggesting an increase in capital investment brings about a short-run decrease in $\mathrm{CO}_{2}$ emissions of the $\mathrm{G} 20$ nations.

Regarding the interaction terms, evidence suggests that interacting renewable energy with capital investment negatively impacts short-run carbon emissions, while it is positive for the interaction between non-renewable energy and capital investment. Interestingly, Table 8 shows the interaction between non-renewable energy and capital investment exerting a significant short-run positive impact on pollution at $5 \%$. This is unlike the insignificant short-run effects that characterise the other major explanatory variables in models I-III. Finally, concerning the error correction terms (ECT), the ECTs of model I, model II, and model III are significantly negative at critical levels. This corroborates the earlier long-run nexus confirmed by Westerlund (2007) cointegration test. It also means that the models are well specified as there is a convergence towards the long-run path.

Long-run estimates in Table 9 show that in both models I and II, renewable energy negatively and significantly impacts carbon emissions while keeping all the other explanatory variables constant. This means that short- and long-run emissions are lowered by renewable energy in G20. Also,

Table 7 Panel cointegration test based on Westerlund (2007) with bootstrap

\begin{tabular}{|c|c|c|c|c|}
\hline \multicolumn{5}{|c|}{ Hypothesis: There is no existence of cointegration } \\
\hline Statistic & Value & Z-value & Probability & $\begin{array}{l}\text { Robust } \\
\text { Probabil- } \\
\text { ity }\end{array}$ \\
\hline \multicolumn{5}{|c|}{ Model I } \\
\hline $\mathrm{Gt}^{* * *}$ & -2.303 & -0.447 & 0.328 & 0.000 \\
\hline $\mathrm{Ga}^{* * *}$ & -6.880 & 2.750 & 0.997 & 0.000 \\
\hline $\mathrm{Pt}^{* * *}$ & -8.777 & -0.471 & 0.319 & 0.000 \\
\hline $\mathrm{Pa}^{* * *}$ & -6.392 & 0.899 & 0.816 & 0.000 \\
\hline \multicolumn{5}{|c|}{ Model II } \\
\hline $\mathrm{Gt}^{* * *}$ & -2.445 & -0.081 & 0.468 & 0.000 \\
\hline $\mathrm{Ga} * * *$ & -5.604 & 4.313 & 1.000 & 0.000 \\
\hline $\mathrm{Pt}^{* * *}$ & -12.689 & -2.869 & 0.002 & 0.000 \\
\hline $\mathrm{Pa}^{* * *}$ & -10.084 & -0.038 & 0.485 & 0.000 \\
\hline \multicolumn{5}{|c|}{ Model III } \\
\hline $\mathrm{Gt}^{* * *}$ & -1.939 & 1.112 & 0.867 & 0.000 \\
\hline $\mathrm{Ga}^{* * *}$ & -5.067 & 3.779 & 1.000 & 0.000 \\
\hline $\mathrm{Pt}^{* * *}$ & -13.916 & -4.677 & 0.000 & 0.000 \\
\hline $\mathrm{Pa}^{* * *}$ & -10.341 & -1.266 & 0.103 & 0.000 \\
\hline
\end{tabular}

*** indicates $1 \%$ critical level. 
Table 8 Baseline Estimates for G20, lag length chosen based on AIC $(\max l a g=1)$

Explanatory
variables

Model I: ARDL $(1,1,1,1,1,1,1)$

Model II: ARDL $(1,1,1,1,1,1,1,1)$

Model III: ARDL $(1,1,1,1,1,1,1)$

I

A. Short-run panel results

\begin{tabular}{llll}
\hline$E C T$ & $-0.06160 *(0.03532)$ & $-0.15312 * * *(0.05479)$ & $-0.09392 * *(0.0459)$ \\
$\Delta Y$ & $0.00014(0.00046)$ & $-0.00012(0.00072)$ & $0.00030(0.00027)$ \\
$\Delta Y^{2}$ & $-4.79342(3.06980)$ & $-2.14787(3.41107)$ & $-3.70155(2.91370)$ \\
$\Delta R E N$ & $-0.74144(0.67251)$ & $-1.08328(1.03392)$ & - \\
$\Delta N E N$ & $0.23260(0.14983)$ & $0.26906(0.18002)$ & - \\
$\Delta C I$ & - & $-0.02997(0.01975)$ & - \\
$\Delta R E N C I$ & - & - & $-0.05080(0.04484)$ \\
$\Delta N E N C I$ & - & - & $0.00072 * *(0.00034)$ \\
$\Delta$ FDI & $-0.00524(0.01326)$ & $0.00155(0.00933)$ & $-0.00398(0.01043)$ \\
$\Delta$ TO & $0.00777(0.00678)$ & $0.00765(0.00728)$ & $0.00557(0.00721)$ \\
Constant & $0.55216 *(0.30516)$ & $2.88186^{* * *}(0.99280)$ & $1.18047 * *(0.52268)$
\end{tabular}

Parentheses display the standard error; *, **, *** mean $10 \%, 5 \%, 1 \%$ critical level.

Table 9 Baseline estimates for G20, lag length chosen based on AIC (max lag $=1)$

\begin{tabular}{|c|c|c|c|}
\hline \multirow{4}{*}{$\begin{array}{l}\text { Explanatory } \\
\text { variables }\end{array}$} & \multirow[t]{3}{*}{ Explained variable: $\Delta \mathrm{CO}_{2}$} & \multicolumn{2}{|c|}{ Model I: ARDL $(1,1,1,1,1,1,1)$} \\
\hline & & \multicolumn{2}{|c|}{ Model II: ARDL $(1,1,1,1,1,1,1,1)$} \\
\hline & & \multicolumn{2}{|c|}{ Model III: ARDL $(1,1,1,1,1,1,1)$} \\
\hline & I & II & III \\
\hline \multicolumn{4}{|c|}{ B. Long-run panel results } \\
\hline$Y$ & $0.00063 * * *(0.00010)$ & $0.00019 * * *(0.00002)$ & $0.00039 * * *(0.00005)$ \\
\hline$Y^{2}$ & $-1.51997 * * *(0.34945)$ & $-0.46370 * * *(0.17760)$ & $-0.47086^{* * *}(0.14467)$ \\
\hline REN & $-0.23567 * * *(0.04133)$ & $-0.20850 * * *(0.02441)$ & - \\
\hline$N E N$ & $0.30637 * * *(0.08751)$ & $-0.05679 * *(0.02441)$ & - \\
\hline$C I$ & - & $0.09153 * * *(0.01312)$ & - \\
\hline RENCI & - & - & $-0.00514 * * *(0.00047)$ \\
\hline NENCI & - & - & $0.00164 * * *(0.00012)$ \\
\hline$F D I$ & $0.10687 * * *(0.03960)$ & $-0.06066^{* *}(0.02425)$ & $0.15927 * * *(0.03096)$ \\
\hline TO & $-0.03308 * * *(0.00917)$ & $-0.00962 * *(0.00457)$ & $-0.01162 * *(0.00453)$ \\
\hline
\end{tabular}

Parentheses display the standard error; *, **, *** mean $10 \%, 5 \%, 1 \%$ critical levels non-renewable energy positively and significantly impacts $\mathrm{CO} 2$ emissions in model I (i.e., without the inclusion of capital investment). However, when capital investment is controlled for in model II, consumption of non-renewable energy negatively and significantly impacts G20 emissions. Meanwhile, capital investment exerts a positive and considerable impact on long-run emissions. Therefore, while the result shows that capital investment raises long-run emissions, its presence in the model has helped reverse the positive effects of non-renewable energy use on pollution. Regarding the interaction terms, the long-run findings suggest that the interaction between renewable energy and capital investment exerts a negative and significant effect on pollution. Meanwhile, non-renewable energy and capital investment interaction positively and significantly correlate with pollution. Interestingly, unlike the short-run results, all major variables significantly drive long-run carbon pollution at $5 \%$ and $1 \%$ significance levels. Economic implications and intuitions of these findings are discussed next.

\section{Discussion of findings}

The empirical findings have several economic implications. Firstly, the fact that renewable energy reduces both longand short-run emissions suggests that renewable energy consumption does not increase pollution in G20 economies. 
This result is in tune with Shafiei and Salim (2014) and Chen et al. (2019). Moreover, the result is in sync with Bento and Moutinho (2016) for Italy and Dogan and Seker (2016) for top renewable energy nations. Again, having confirmed that non-renewable energies worsened short- and long-run pollutions when estimated without capital investment, it implies that it constitutes the main pollution concern among the G20 nations. These findings corroborate the earlier results, such as Shafiei and Salim (2014), Bento and Moutinho (2016), Dogan and Seker (2016), and Chen et al. (2019). Moreover, since results show that capital investment exerts a short-run negative effect on $\mathrm{CO}_{2}$ emissions, it means that $\mathrm{G} 20$ nations can use investment technologies to reduce $\mathrm{CO}_{2}$ emissions. It can also help the G20 countries meet their short-run target for the early 2020 period. It also means that to achieve their 2020 and 2030 goals, they can jointly leverage using environmentally friendly machines to reduce carbon emissions. The capital investment result aligns with Mesagan (2021a) for BRICS.

Moreover, the fact that the inclusion of capital investment reversed the negative effect of non-renewable energy on long-run emissions is striking. The intuition is that capital investment is crucial for reducing the long-run environmental impacts of fossil fuels among the G20 nations. It also means that if the G20 countries can only use clean technologies for production, non-renewable energy consumption will become a tool to reduce pollution instead of increasing it. Besides, since findings show that energy from nonrenewable sources positively impacts emissions of $\mathrm{CO}_{2}$, it can only reduce pollution in G20 if its proportion in the overall energy mix is lowered. Also, since interacting capital investment with renewable energy reduces long- and shortrun pollution, it re-emphasises the importance of renewable energy in the energy mix of the G20 economies. It implies that if energy consumption is to work through the capital investment channel to lower pollution in the G20, the share of renewable energies must increase compared to the nonrenewable ones in their energy mix. Thus, reducing pollution by augmenting non-renewable energy use with capital investment is not an option for G20 nations without significantly reducing fossil fuel energy use. It, therefore, means that fossil fuel energies are the main pollution drivers in the G20, which can be remedied by augmenting it with clean technologies to fast-track global pollution reductions.

\section{Conclusion}

The paper analysed the impact of energy use in pollution reduction through the capital investment channel in G20 economies. The study covered the period straddling 1990-2017 using the dynamic heterogeneous panel analysis of the pooled mean group. This study deviated from previous panel studies by accounting for cross-sectional dependence since the considered countries are heterogeneous and are cross-sectionally dependent. The study equally disaggregated energy consumption into non-renewable and renewable to better understand the energy-pollution nexus. Hence, the models are estimated with and without augmenting energy consumption with capital investment. The findings showed renewable energy as lowering $\mathrm{CO}_{2}$ emissions both in the short and long runs, while non-renewable energy increased carbon emissions. Meanwhile, capital investment reduced short-run pollution, but with a contrary result in the long run. Lastly, investment augmented with renewable energy exerts reducing impacts on pollution both in the long and short runs; however, it amplifies pollution impacts when interacted with non-renewable energy. To this end, the study concludes that capital investment provides the crucial channel for reducing pollution in the G20.

Given these findings, we suggest that if energy consumption is to work through the capital investment channel to lower pollution in the G20, the share of renewable energies must increase significantly. Furthermore, G20 countries should also focus on using only clean technologies for production as this will help in augmenting non-renewable energy use to reduce pollution levels. However, the use of renewable energies seems limited for a few countries within the G20 group, as presented in Table 1. Therefore, it is suggested that various national governments in G20 economies should collaborate with private investors to encourage sustainable investments in solar, wind, and other sources of renewable energies. This will help significantly reduce global emissions below the $20^{\circ} \mathrm{C}$ and preferably $1.50^{\circ} \mathrm{C}$ preindustrial levels.

\section{Future outlook for the $\mathbf{G 2 0}$ nations}

This study throws up several implications for pollution reduction in the G20 nations. Firstly, it is expected that G20 economies will invest massively in more miniature carbonladen plants in their quest to fulfil their part of the Paris Agreement. Once this happens, the composition effect of emissions would fall and $\mathrm{CO}_{2}$ too. Secondly, this study has further deepened the need for massive investment in renewable energy in coping with the challenges posed by climate change. To this end, we believe that the G20 nations will leverage this result to continue their strides in expanding their solar power plants and other biofuels. Thirdly, our result indicates that capital investment provides the augmenting channel for reducing G20's non-renewable energy pollution with the condition that the share of renewable energy rises in the mix. Finally, it means that all is not doom and gloom with fossil fuel energy. Hence, projecting into the future up to 2050 , the G20 should be looking at boosting climatefriendly investments while still utilising their fossil energy 
in the short term and gradually building up their renewable energy capacity for the long term.

Author contribution $\mathrm{KBJ}$ presented the literature review, and handled the correction and complete editorial of the paper.

EPM wrote the stylised facts, methodology, and analysed the results.

All the authors conceptualised the study, and read and approved the final manuscript.

Availability of data and materials The data used in this study are available from the corresponding author on reasonable request

\section{Declarations}

Ethics approval and consent to participate Not applicable

Consent for publication Not applicable

Competing interests The authors declare no competing interests.

\section{References}

Ajide KB, Ibrahim RL (2021) Threshold effects of capital investment on carbon emissions in G20 economies. Environ Sci Pollut Res. https://doi.org/10.1007/s11356-021-13046-x

Andreoni J, Levinson A (2001) The simple analytics of the environmental Kuznets curve. J Public Econ 80(2):269-286

Appunn K (2018). Germany's greenhouse gas emissions and climate targets. Available at: https://www.cleanenergywire.org/facts heets/germanys-greenhouse-gas-emissions-and-climate-targe ts. Accessed 01/05/2019.

Baloch MA, Zhang J, Iqbal K, Iqbal Z (2019) The effect of financial development on ecological footprint in BRI countries: evidence from panel data estimation. Environ Sci Pollut Res 26(6):6199-6208

Bento JPC, Moutinho V (2016) $\mathrm{CO}_{2}$ emissions, non-renewable and renewable electricity production, economic growth, and international trade in Italy. Renew Sust Energ Rev 55:42-155

Bernard J, Clavet F, Ondo J (2004) Electricity production and $\mathrm{CO}_{2}$ emission reduction: dancing to a different tune across the Canada-US border. Can Public Policy 30(4):401-426

Blomquist GC, Cave LA (2008) Environmental policy in the European Union: fostering the development of pollution havens? Ecol Econ 65:253-261

BP Statistical Review of World Energy (2018). Data on world energy by countries and regions. Available at: http://www.bp.com/stati sticalreview. Accessed 06/09/2018.

Breitung J (2001) The local power of some unit root tests for panel data. In: Nonstationary panels, panel cointegration, and dynamic panels. Emerald Group Publishing Limited, Syracuse, pp 161-177

Charfeddine L, Kahia M (2019) Impact of renewable energy consumption and financial development on $\mathrm{CO} 2$ emissions and economic growth in the MENA region: a panel vector autoregressive (PVAR) analysis. Renew Energy 139:198-213

Chen Y, Wang Z, Zhong Z (2019) CO2 emissions, economic growth, renewable and non-renewable energy production and foreign trade in China. Renew Energy 131:208-216

Climate Action Tracker (2019). Climates analytics for countries. Available at www.climateactiontracker.org/countries.html. Accessed 25/04/2019.
Cowan WN, Chang T, Inglesi-Lotz R, Gupta R (2014) The nexus of electricity consumption, economic growth and $\mathrm{CO} 2$ emissions in the BRICS countries. Energy Policy 66:359-368

Dasgupta S, Laplante B, Wang H, Wheeler D (2002) Confronting the environmental Kuznets curve. J Econ Perspect 16(1):147-168

DEE (2017). 2017 Review of climate change policies. Available at https://www.environment.gov.au/system/files/resources/18690 271-59ac-43c8-aee1-92d930141f54/files/2017-review-of-clima te-change-policies.pdf. Accessed 09/06/2019.

Ding Q, Khattak SI, Ahmad M (2021) Towards sustainable production and consumption: assessing the impact of energy productivity and eco-innovation on consumption-based carbon dioxide emissions (CCO2) in G-7 nations. Sustain Prod Consump 27:254-268

Dogan E, Seker F (2016) The influence of real output, renewable and non-renewable energy, trade and financial development on carbon emissions in the top renewable energy countries. Renew Sust Energ Rev 60:1074-1085

Eregha P, Mesagan E (2017) Energy consumption, oil price and macroeconomic performance in energy dependent African countries. Appl Econ 46:74-89

Eregha PB, Mesagan EP (2020) Oil resources, deficit financing and per capita GDP growth in selected oil-rich African nations: a dynamic heterogeneous panel approach. Res Policy 66:101615

Frankel JA, Rose AK (2005) Is trade good or bad for the environment? Sorting out the causality. Rev Econ Stat 87(1):85-91

Global Carbon Atlas (2018). Data on global $\mathrm{CO}_{2}$ emissions. Available at: http://www.globalcarbonatlas.org/en/content/welcome-carbonatlas. Accessed $5^{\text {th }}$ June, 2019.

Grubb M, Sha F, Spencer T, Hughes N, Zhang Z, Agnolucci P (2015) A review of Chinese $\mathrm{CO} 2$ emission projections to 2030: the role of economic structure and policy. Clim Pol 15(sup1):S7-S39

Haider S, Adil M, Ganaie A (2019) Does industrialisation and urbanisation affect energy consumption: a relative study of India and Iran? Econ Bull 39(1):176-185

Halicioglu F (2009) An econometric study of CO2 emissions, energy consumption, income and foreign trade in Turkey. Energy Policy 37(3):1156-1164

Hope M (2014). Dissecting Germanys new Climate Action Plan. Available at: https://www.carbonbrief.org/dissecting-germanys-newclimate-action-plan. [Accessed 01/04/2019]

Hughes, T. P., Baird, A. H., Bellwood, D. R., Card, M., Connolly, S. R., Folke, C., Grosberg, R., ..... \& Roughgarden, J. (2003). Climate change, human impacts, and the resilience of coral reefs. Science, 301(5635), 929-933.

IEA (2018). Engagement worldwide, co-operation with key international fora, G20. Available at http://www.iea.org/topics/engag ementworldwide/subtopics/cooperationwithkey internationalfo $\mathrm{ra} / \mathrm{g} 20 /$. [Accessed 23/04/2019]

Im KS, Pesaran MH, Shin Y (2003) Testing for unit roots in heterogeneous panels. J Econ 115(1):53-74

Inglesi-Lotz R, Dogan E (2018) The role of renewable versus nonrenewable energy to the level of $\mathrm{CO} 2$ emissions a panel analysis of sub-Saharan Africa's Big 10 electricity generators. Renew Energy 123:36-43

Intergovernmental Panel on Climate Change (IPCC) (2015) Climate change 2014: mitigation of climate change, 3rd edn. Cambridge University Press, Cambridge

International Institute for Sustainable Development (IISD) (2020), Anna Geddes, Ivetta Gerasimchuk, Balasubramanian Viswanathan, Angela Picciariello, Bronwen Tucker, Alex Doukas, Vanessa Corkal, Mostafa Mostafa, Joachim Roth, Anissa Suharsono and Ipek Gençsü. "Doubling back and doubling down: G20 scorecard on fossil fuel funding. Published by the International Institute for Sustainable Development.

Kerr RA (2007) Scientists tell policymakers we're all warming the world. Science 315(5813):754-757 
Khan AQ, Saleem N, Fatima ST (2018) Financial development, income inequality, and $\mathrm{CO} 2$ emissions in Asian countries using STIRPAT model. Environ Sci Pollut Res 25(7):6308-6319

Kuramochi T (2014). GHG mitigation in Japan: an overview of the current policy landscape. World Resources Institute Working Paper, June 2014 version. Available at https://www.wri.org/ sites/default/files/wri_workingpaper_japan_final_ck_6_11_14. pdf. Accessed 14/05/19

Levin A, Lin CF, Chu CSJ (2002) Unit root tests in panel data: asymptotic and finite-sample properties. J Econ 108(1):1-24

Li Z, Xu N, Yuan J (2015) New evidence on trade-environment linkage via air visibility. Econ Lett 128:72-74

Masiero G (2011) Developments of biofuels in Brazil and East Asia: experiences and challenges. Revista Brasileira de Política Int 54(2):97-117

Mazumdaru S (2017). Climate change - India battles to balance economy and environment. Available at http://p.dw.com/p/2mxvR. Accessed on April 18, 2019.

McMichael AJ, Woodruff RE, Hales S (2006) Climate change and human health: present and future risks. Lancet 367(9513):859-869

Mesagan EP (2015) Economic growth and carbon emission in Nigeria. IUP J Appl Econ 14(4):61-75

Mesagan EP (2021a) Efficiency of financial integration, foreign direct investment and output growth: policy options for pollution abatement in Africa. Econ Issues 26(1):1-19

Mesagan EP (2021b). Environmental sustainability in Sub-Saharan Africa: the case of production and consumption activities. J Knowl Econ 1-28.

Mesagan EP, Nwachukwu MI (2018) Determinants of environmental quality in Nigeria: assessing the role of financial development. Econ Res Finance 3(1):55-78

Mesagan PE, Olunkwa NC (2020) Energy consumption, capital investment and environmental degradation: the African experience. Forum Sci Oecon 8(1):5-16

Mesagan PE, Olunkwa NC (2022) Heterogeneous analysis of energy consumption, financial development and pollution in Africa: is regulatory quality important? Util Policy 74:101328

Mesagan PE, Isola WA, Ajide KB (2019) The capital investment channel of environmental improvement: evidence from BRICS. Environ Dev Sustain 21(4):1561-1582

Mesagan EP, Ajide KB, Vo XV (2020) Dynamic heterogeneous analysis of pollution reduction in SANEM countries: lessons from the energyinvestment interaction. Environ Sci Pollut Res 28(5):5417-5429

Mesagan PE, Omojolaibi JA, Umar DI (2018) Trade intensity, energy consumption and environment in Nigeria and South Africa. Ovidius University Annals Economic Sciences Series 18(1):33-38

Mesagan EP, Akinyemi AK, Yusuf IA (2021) Financial integration and pollution in Africa: the role of output growth and foreign direct investment. Int J Big Data Min Global Warm 3(1):1-21

Muller DB, Liu G, Løvik AN, Modaresi R, Pauliuk S, Steinhoff FS, Bratteb $\varnothing \mathrm{H}$ (2013) Carbon emissions of infrastructure development. Environ Sci Technol 47(20):11739-11746

Pata UK (2018) Renewable energy consumption, urbanization, financial development, income and $\mathrm{CO} 2$ emissions in Turkey: testing EKC hypothesis with structural breaks. J Clean Prod 187:770-779

Patz JA, Campbell-Lendrum D, Holloway T, Foley JA (2005) Impact of regional climate change on human health. Nature 438(7066):310-317

Pesaran MH (2007) A simple panel unit root test in the presence of cross-section dependence. J Appl Econ 22(2):265-312

Pesaran MH, Chudik A (2014) Aggregation in large dynamic panels. J Econ 178:273-285

Pesaran MH, Smith R (1995) Estimating long-run relationships from dynamic heterogeneous panels. J Econ 68(1):79-113

Pesaran MH, Shin Y, Smith RP (1999) Pooled mean group estimation of dynamic heterogeneous panels. J Am Stat Assoc 94(446):621-634
Safdari M, Barghandan A, Shaikhi AM (2013) Has $\mathrm{CO}_{2}$ emission increased the Iranian economic growth? Int J Acad Res Bus Soc Sci 3(1):314-352

Shafiei S, Salim RA (2014) Non-renewable and renewable energy consumption and $\mathrm{CO} 2$ emissions in OECD countries: a comparative analysis. Energy Policy 66:547-556

Shahbaz M, Hye QMA, Tiwari AK, Leitão NC (2013) Economic growth, energy consumption, financial development, international trade and CO2 emissions in Indonesia. Renew Sust Energ Rev 25:109-121

Shahsavari A, Akbari M (2018) Potential of solar energy in developing countries for reducing energy-related emissions. Renew Sust Energ Rev 90:275-291

Sharif A, Raza SA, Ozturk I, Afshan S (2019) The dynamic relationship of renewable and nonrenewable energy consumption with carbon emission: a global study with the application of heterogeneous panel estimations. Renew Energy 133:685-691

Sims RE, Rogner HH, Gregory K (2003) Carbon emission and mitigation cost comparisons between fossil fuel, nuclear and renewable energy resources for electricity generation. Energy Policy 31(13):1315-1326

Sodersten CJ, Wood R, Hertwich (2017) Environmental impacts of capital formation. J Ind Ecol 22:55-67. https://doi.org/10.1111/jiec.12532

Soytas U, Sari R, Ewing BT (2007) Energy consumption, income, and carbon emissions in the United States. Ecol Econ 62(3-4):482-489

Statista (2018). Breakdown of G20 countries with the highest CO2 emissions, 2016. Available at: https://www.statista.com/statistics/ 723163/g20-carbon-dioxide-emissions/ [Accessed 24/04/2019]

Stern DI (2004) The rise and fall of the environmental Kuznets curve. World Dev 32(8):1419-1439

Stolyarova E (2013) Carbon dioxide emissions, economic growth and energy mix: empirical evidence from 93 countries, EcoMod 2013, Prague $\langle$ hal-01639531

Tang CF, Tan BW (2015) The impact of energy consumption, income and foreign direct investment on carbon-dioxide emissions in Vietnam. Energy 79:447-454

Wang P, Wu W, Zhu B, Wei Y (2013) Examining the impact factors of energy-related $\mathrm{CO} 2$ emissions using the STIRPAT model in Guangdong Province, China. Appl Energy 106:65-71

Westerlund J (2007) Testing for error correction in panel data. Oxf Bull Econ Stat 69(6):709-748

Wilson R (2014). America versus China: the new reality of global energy. Available at www.theenergycollective.com/robertwils on 190/380971/america-versus-china-what-difference-decademakes. Accessed March 18, 2019.

World Development Indicators (2019). The World Bank, Databank. Available at: http://databank.worldbank.org/data/reports.aspx? source=world-development-indicators. Accessed March 25th, 2019.

Xian Y, Wang K, Wei YM, Huang Z (2019) Would China's power industry benefit from nationwide carbon emission permit trading? An optimization model-based ex post analysis on abatement cost savings. Appl Energy 235:978-986

Yao C, Feng K, Hubacek K (2015) Driving forces of CO2 emissions in the G20 countries: an index decomposition analysis from 1971 to 2010. Ecol Inform 26:93-100

Zhang XP, Cheng XM (2009) Energy consumption, carbon emissions, and economic growth in China. Ecol Econ 68(10):2706-2712

Zhang C, Zhou X (2016) Does foreign direct investment lead to lower $\mathrm{CO}_{2}$ emissions? Evidence from a regional analysis in China. Renew Sust Energ Rev 58:943-951

Zhou N, Fridley D, McNeil M, Zheng N, Ke J, Levine M (2011) China's energy and carbon emissions outlook to 2050 (No. LBNL4472E). Ernest Orlando Lawrence Berkeley National Laboratory, Berkeley

Publisher's note Springer Nature remains neutral with regard to jurisdictional claims in published maps and institutional affiliations. 